\title{
Air Pollutant Levels during the Large-scale Social Restriction Period and its Association with Case Fatality Rate of COVID-19
}

Special Issue:

Special Issue on COVID-19 Aerosol Drivers, Impacts and Mitigation (XV)

\section{Muhammad Rendana*}

Department of Chemical Engineering, Faculty of Engineering, Universitas Sriwijaya, Indralaya 30662 South Sumatera, Indonesia

\section{ABSTRACT}

The COVID-19 outbreak has caused millions of deaths in all over the world since it was declared by the World Health Organization (WHO) as a pandemic in March 2020. To stop the deadly spread of the virus, many countries, including Indonesia, have applied the 'Large-scale Social Restriction' (LSSR) policy. Numerous studies have reported positive impacts of air quality due to this policy. However, in Indonesia, data on the impacts of LSSR on air quality are still sparse. Therefore, this study aims to analyze changes in air quality at before and during the LSSR periods in the South Sumatera Province, Indonesia using the satellite-based observations of particulate matter $\left(\mathrm{PM}_{10}\right)$, sulfur dioxide $\left(\mathrm{SO}_{2}\right)$, nitrogen dioxide $\left(\mathrm{NO}_{2}\right)$ and carbon monoxide (CO). The results showed that the concentrations of the measured pollutants markedly declined during the LSSR period from the highest was $\mathrm{SO}_{2}(98.90 \%)$ and followed by $\mathrm{NO}_{2}$ (34.79\%), $\mathrm{CO}(12.70 \%)$ and $\mathrm{PM}_{10}(11.54 \%)$, respectively. The emissions from biomass burning activities were expected as a major source of air pollutant during the LSSR. Furthermore, we found a positive association between $\mathrm{PM}_{10}$ and the case fatality rate of COVID-19 in the study area $(r=0.514, p<0.05)$. Finally, this study concluded that the implementation of LSSR could reduce air pollutants concentration in the study area while a higher $\mathrm{PM}_{10}$ exposure could increase the risk of death from COVID-19. The output of the study can be used to arrange air quality management practice and COVID-19 transmission control in Indonesia.

Keywords: Air pollutant, Large-scale social restriction, Case fatality rate, COVID-19, $\mathrm{PM}_{10}$

\section{INTRODUCTION}

The World Health Organization (WHO) has labelled the COVID-19 outbreak as a global pandemic in March 2020 (WHO, 2020). In many countries, including Indonesia, pandemic control measures have been implemented by government. In Indonesia, one of the control measures is known as the Large-scale Social Restriction (LSSR) to avoid the transmission of COVID-19. During the LSSR period, only limited essential services such as public health center, food supply chain management and logistics are allowed to operate, whereas vehicles, industries and power plant activities are restricted which attribute to decline air pollutants level. Thus, there has been a positive impact of decreasing air pollution because of the LSSR.

Air quality is a prominent factor that any authorities needs to take as a one of priority of their policy. Particulate matter, sulfur dioxide $\left(\mathrm{SO}_{2}\right)$, nitrogen dioxide $\left(\mathrm{NO}_{2}\right)$, carbon monoxide $(\mathrm{CO})$ and ozone $\left(\mathrm{O}_{3}\right)$ will give bad effects on human health if their presence at high concentrations (Lave and Seskin, 2013). Several studies have found that transportation, industries and power plant emissions contributed significantly to atmospheric pollution (Swietlicki et al., 1996). Additionally, biomass burning, agricultural land burning and forest fires also increase to atmospheric pollution loads (Ravindra et al., 2020).

Recently, a satellite-based measurement of air pollutant during the COVID-19 pandemic from 
the ESA (European Space Agency) have reported changes in $\mathrm{NO}_{2}$ conecntration using the Tropospheric Monitoring Instrument on the Sentinel-5 satellite which indicated impact of lockdown in European countries resulted in $\mathrm{NO}_{2}$ level reduction. In Chinese cities, Dutheil et al. (2020) reported $\mathrm{NO}_{2}$ was measured by the Tropospheric Monitoring Instrument indicated about $30 \%$ reduction in tropospheric $\mathrm{NO}_{2}$ level. The Ozone Monitoring Instrument on NASA's Aura satellite data also obtained a similar result (NASA, 2020). The reductions were mostly caused to restricted industrial and social activities, and reduced number of vehicles.

Many studies have reported a significant association between environmental factors (meteorological and air pollution variables) and COVID-19 cases. Tosepu et al. (2020) found temperature was significantly associated with COVID-19 spread in Jakarta, Indonesia ( $r=0.392$; $\mathrm{p}<0.01$ ). Temperature along with wind speed indicated a significant correlation with COVID-19 transmission (Babu et al., 2020; Pani et al., 2020; Rendana, 2020). Relative humidity was also a contributing factor for airborne transmission of COVID-19 (Ahlawat et al., 2020; Ma et al., 2020).

Furthermore, recent studies have revealed that the COVID-19 incidences had a strong association with the particulate matter concentration in air (Zoran et al., 2020). Exposure to ambient particulate matter has been noted to increase the risks of mortality due to pulmonary diseases (Ling and van Eeden, 2009; Yang et al., 2011). It was supported by previous study where the particulate matter is positively correlated with case fatality rate from coronavirus infection (SARS-CoV-1) (Cui et al., 2003). For SAR-CoV-2 (COVID-19), recent studies have reported particulate matter concentration was also positively associated with case fatality rate of COVID-19 and it might affect COVID-19 prognosis (Yao et al., 2020). Similar result also obtained by Patra et al. (2021) who found $\mathrm{PM}_{2.5}$ concentration had a positive association with COVID-19 fatality rates $(r=0.52)$. As whole, those above-studies have suggested the particulate matter could possibly carry viruses as carrier and transmit viruses through air. However, they focused only on particulate matter and they did not elaborate other important pollutants such as $\mathrm{SO}_{2}, \mathrm{NO}_{2}, \mathrm{CO}$ and $\mathrm{O}_{3}$.

Several studies have also carried out to investigate the impact of COVID-19 lockdown on air quality in a certain area. For instance, Ezani et al. (2020) reported decline in level of $\mathrm{PM}_{2.5}$ was recorded during COVID-19 lockdown in suburban Malaysia. A study by Xu et al. (2020) also found there was reductions of air pollutants during the COVID-19 pandemic such as $30.1 \%\left(\mathrm{PM}_{2.5}\right)$, 40.5\% (PM 10), 33.4\% ( $\left.\mathrm{SO}_{2}\right), 27.9 \%(\mathrm{CO})$ and 61.4\% $\left(\mathrm{NO}_{2}\right)$ which recorded in Wuhan, Jingmen and Enshi. In Indonesia, the air quality was found better during the LSSR period in the Jakarta province and its surrounding provinces (Pramana et al., 2020). However, this study focused on the air quality index and did not specifically explain regarding air pollutant concentration. Also, this study only covered provinces in Java Island, wheras there was not any studies regarding air quality in provinces of Sumatera Island during COVID-19 pandemic. Although ground monitoring station offered a good measurement of air quality, but some areas in this country, the limited station for air quality measurement is a primary issue to obtain the best observation. Therefore, low-cost air quality measurement for air quality based on satellite remote sensing has been applied for this current time. This technique provide a good air pollution data at high spatial-temporal resolutions and show a good accuracy (Kanniah et al., 2020).

Therefore, this current study aims to analyze the air pollutants $\mathrm{PM}_{10}, \mathrm{SO}_{2}, \mathrm{NO}_{2}$ and $\mathrm{CO}$ in the South of Sumatera Province at the before the LSSR and during the LSSR periods using satellitebased observation of air polllutant. The effect of meteorological factors and wind trajectory will be assessed using the HYSPLIT model from NOAA. Moreover, because of few studies have quantified the effect of air pollutants on case fatality rate of COVID-19. Therefore, this study also analyzes the relationship between $\mathrm{PM}_{10} \mathrm{SO}_{2}, \mathrm{NO}_{2}$ and $\mathrm{CO}$ with case fatality rate of COVID-19 in the South of Sumatera Province. As a whole, this study will offer a new insight in formulating air quality management strategies and COVID-19 transmission control measures.

\section{METHODS}

\subsection{Satellite-based Observation of Air Pollutants}

Satellite retrievals of aerosol particles and trace gases data were employed to study a satellitebased observation to assess the air quality distribution. Particulate matter $10\left(\mathrm{PM}_{10}\right)$, retrieved from the MODIS-Terra Spacecraft. The $\mathrm{PM}_{10}$ was measured daily using the Aerosol Optical Depth (AOD) 
with $0.55 \mu \mathrm{m}$ wavelength at $1^{\circ} \times 1^{\circ}$ resolution. The AOD was performed as a representative for suspended aerosols in the atmosphere, including fine solid particulate matter.

Tropospheric amount of nitrogen dioxide $\left(\mathrm{NO}_{2}\right)$ retrieved as a daily with $0.25^{\circ} \times 0.25^{\circ}$ resolution and measured by the Ozone Monitoring Instrument (OMI) onboard the NASA's Aura Satellite. Column amount of sulfur dioxide $\left(\mathrm{SO}_{2}\right)$ retrieved as a daily with $0.25^{\circ} \times 0.25^{\circ}$ resolution, it was measured by the OMI, an instrument aboard the NASA's Aura Satellite. Carbon monoxide (CO) mole fraction in air was measured daily by Atmospheric Infrared Sounder (AIRS) on NASA's Aqua Satellite at $1^{\circ} \times 1^{\circ}$ resolution. The AIRS applied 3D analysis of the atmospheric column along with trace gases, cloud and surface properties. Overall, the data were compared between before the LSSR (April 1-14, 2020), during the LSSR phase 1 (May 20-June 2, 2020) and the LSSR phase 2 (June 3-16, 2020).

Additionally, ground-level measurements of $\mathrm{NO}_{2}, \mathrm{SO}_{2}, \mathrm{CO}$ and $\mathrm{PM}_{10}$ concentrations were collected from air quality monitoring station (AQMS) in the South Sumatera Province operated by the Ministry of Environment and Forestry of The Republic of Indonesia. All satellite data were directly compared with the AQMS. In order to match with the satellite data, the AQMS data were arranged into a daily basis just like the satellite data acquisition time. A single satellite pixel which located at the nearest point to the AQMS station was then used for the validation, this technique was the same as shown by the other studies (Kanniah et al., 2020; Yang et al., 2020). Statistical analyses such as the R-squared $\left(R^{2}\right)$, the root mean square error (RMSE) and mean absolute error (MAE) were employed to determine accuracy of the satellite data against the AQMS.

\subsection{Trajectory Analysis}

Trajectory analysis was used to find the possible sources which lead to high concentration of air pollutants during the LSSR period. Air pollutants were tracked from the origin sources to the ending point where the data were retrieved by satellite. The assessment was carried out using Hybrid Single Particle Lagrangian Integrated Trajectory model (HYSPLIT) from the National Oceanic and Atmospheric Administration Air Resource Laboratory (NOAA ARL) (Rolph, 2017). The parameter in this model was set in the backward mode for 72 hours and the altitude from 0 to $100 \mathrm{~m}$. For fire hotspot data, VIIRS (Visible Infrared Imaging Radiometer Suite) and MODIS (ModerateResolution Imaging Spectroradiometer) data were obtained from the fire information for resource management system (FIRMS) website for the studied periods over study area (Fig. 1).

\subsection{Case Fatality Rate of COVID-19}

COVID-19 mortality data in study area was obtained from open data portal (http://corona.sum selprov.go.id/). We calculated the case fatality rate of COVID-19, which was specified as cumulative mortality counts divided by cumulative confirmed cases in study area (Eq. (1)). The case fatality rate of COVID-19 was generally defined as a percentage and showed level severity of disease.

Case Fatality Ratio $(C F R)=\frac{\text { Cumulative mortality }}{\text { Cumulative cases }}$

\section{RESULTS AND DISCUSSION}

\subsection{Spatial Distribution of Air Pollutants}

In this study, the satellite data were validated against the AQMS in the South Sumatera region. The validation outputs indicated a good accuracy between the satellite data and the AQMS with $\mathrm{R}^{2}=0.85, \mathrm{RMSE}=0.11$ and $\mathrm{MAE}=0.08$. The remarkable agreement between the satellite data and the AQMS enabled for applying the satellite data to analyze the air pollutants concentrations and their distribution in the study area before and during the LSSR phases.

The $\mathrm{PM}_{10}$ concentration was analyzed in study area before and during the LSSR period (Fig. 2). The period of LSSR had two phases which were May 20-June 2, 2020 ( $1^{\text {st }}$ phase) and June 3-16, 2020 ( $2^{\text {nd }}$ phase). The average $\mathrm{PM}_{10}$ concentration at before the LSSR (April 1-14, 2020), was $28.50 \mu \mathrm{g} \mathrm{m}^{-3}$ and decreased by $7.69 \%$ (LSSR phase 1) and $11.54 \%$ (LSSR phase 2) (Table 1). The northeast and east areas recorded the highest concentration of $\mathrm{PM}_{10}$ during the LSSR period. 

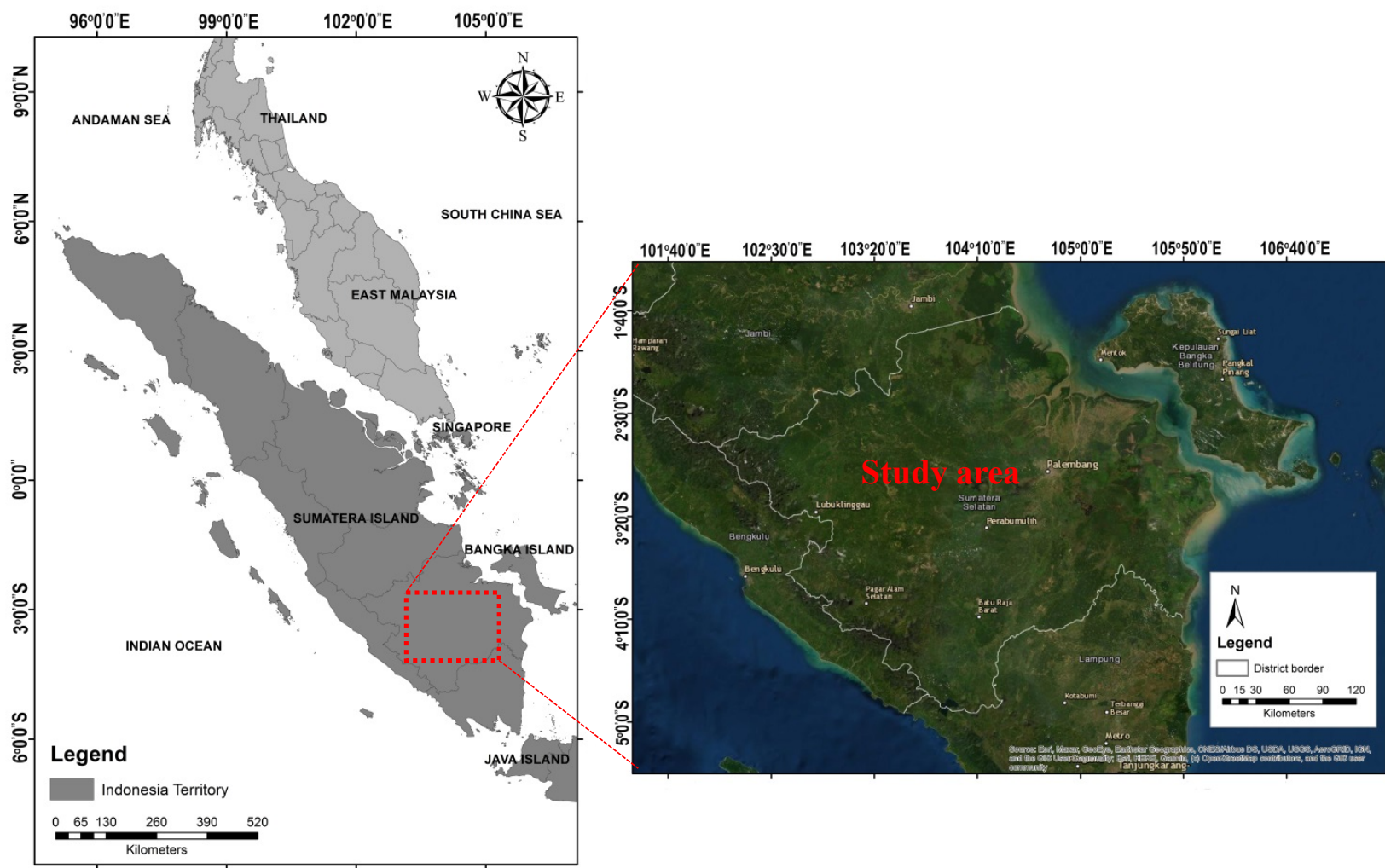

Fig. 1. The location of study area.
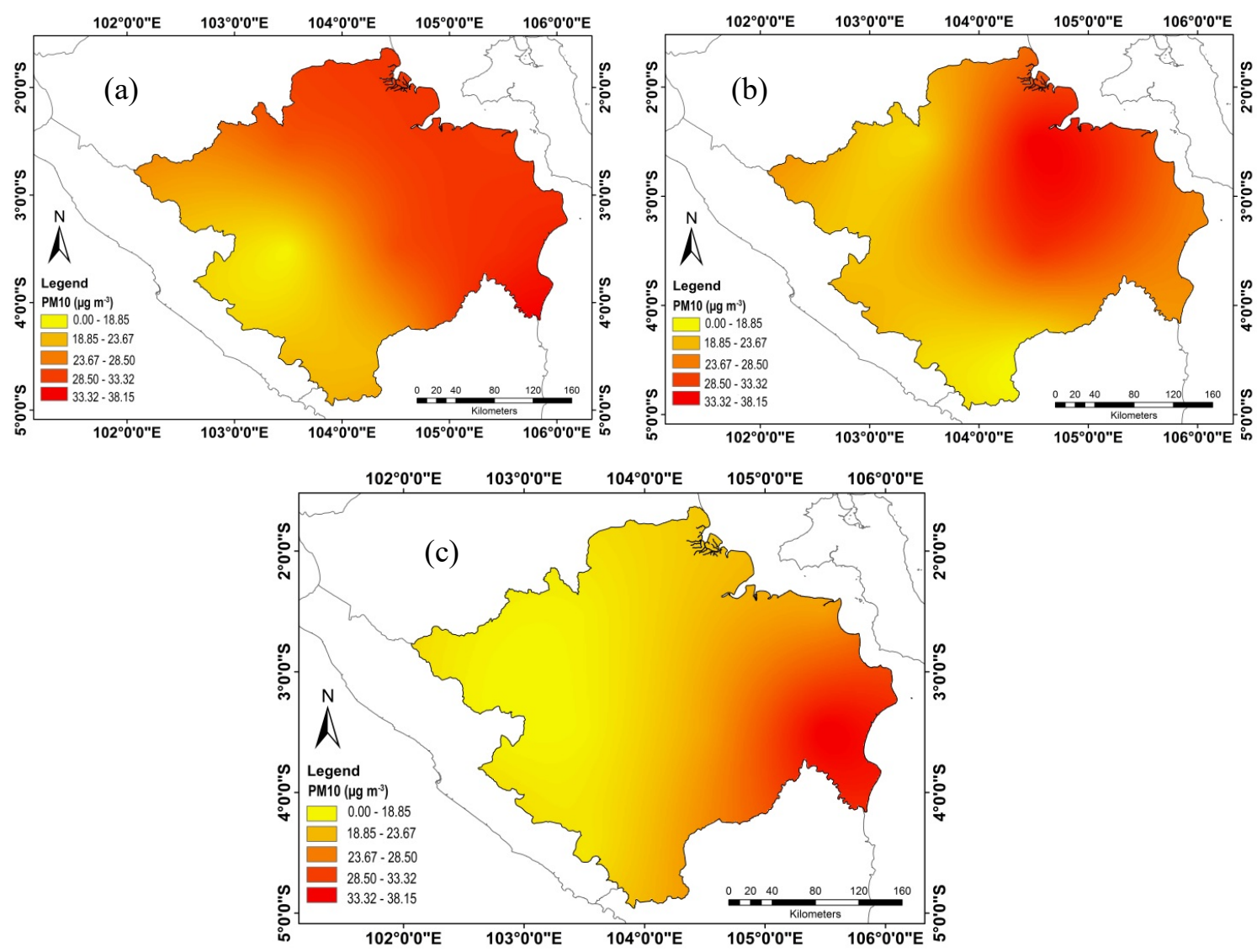

Fig. 2. Spatial distribution of $P M_{10}$ concentration estimated with the MODIS-Terra Satellite over study area (a) before the LSSR, (b) during the LSSR phase 1 and (c) during the LSSR phase 2. 
Table 1. Mean air pollutants concentration over study area between before and during the LSSR period.

\begin{tabular}{llllll}
\hline Air Pollutants & $\begin{array}{l}\text { Before } \\
\text { LSSR }\end{array}$ & $\begin{array}{l}\text { LSSR } \\
\text { Phase 1 }\end{array}$ & $\begin{array}{l}\text { LSSR } \\
\text { Phase 2 }\end{array}$ & $\begin{array}{l}\text { Percentage } \\
\text { reduction after } \\
\text { LSSR 1 (\%) }\end{array}$ & $\begin{array}{l}\text { Percentage } \\
\text { reduction after } \\
\text { LSSR 2 (\%) }\end{array}$ \\
\hline $\mathrm{PM}_{10}$ concentration $\left(\mu \mathrm{g} \mathrm{m}^{-3}\right)$ & 0.28 & 0.26 & 0.23 & 7.69 & 11.54 \\
$\mathrm{SO}_{2}$ Column (DU) & 0.91 & 0.14 & 0.01 & 84.61 & 98.90 \\
$\mathrm{NO}_{2}$ Tropospheric Column $\left(\times 10^{13}\right.$ molecule $\left.\mathrm{cm}^{-2}\right)$ & 107.04 & 69.83 & 86.38 & 34.76 & 19.30 \\
$\mathrm{CO}$, Mole Fraction $(\mathrm{ppbv})$ & 100.03 & 92.52 & 87.33 & 7.51 & 12.70 \\
\hline
\end{tabular}

These areas were mainly encompassed by industries and biomass burning activities. The increase in $\mathrm{PM}_{10}$ might be elucidated because of the high concentration of biomass burning activities in the area, especially in the land use conversion from peatland to agricultural sectors that occurred during the LSSR period. Although, we found a significant reduction of $\mathrm{PM}_{10}$ level during the LSSR phase 2, but when the LSSR phase 1 , the $\mathrm{PM}_{10}$ level was just partly reduced, it was because industrial activities was still in operation. The same situation also found at coal mining areas in India which recorded a positive anomaly ( +11 to $40 \%)$ during the lockdown period because of continuing mining operation (Ranjan et al., 2020).

The average column $\mathrm{SO}_{2}$ concentration in study area showed high reductions, $84.61 \%$ during LSSR phase 1 and $98.90 \%$ during LSSR phase 2 (Table 1). The result was consistent with Filonchyk et al. (2020) who found the low $\mathrm{SO}_{2}$ level also recorded in North China Plain (0.45-0.70 DU), where the area with power plants and coal mining industries during COVID-19 outbreak. In general, the greatest source of $\mathrm{SO}_{2}$ in air was from the burning of fossil fuels by power plants and industrial activities. Spatial distribution map of $\mathrm{SO}_{2}$ concentration indicated that the pollutants were more concentrated in the northwest part of study area (Fig. 3(a)). This area that were along rice mills and food processing plants each recorded high amounts of $\mathrm{SO}_{2}$ (5.43-7.89 DU). Since $\mathrm{SO}_{2}$ could be produced by burning coal, the high $\mathrm{SO}_{2}$ level were observed in the center region of study area (above $5.43 \mathrm{DU}$ ), where there were coal industry and power plants. However, during the LSSR period, $\mathrm{SO}_{2}$ concentrations in the area were found decreasing to the range of 0.512.9 DU (Figs. 3(b)-3(c)). This was because there was a shutdown of factories or industries for a certain period to avoid COVID-19 transmission. In countries all over the world, many industrial operations either shut down or worked with limited capacity because of COVID-19 impact (Chowdhury et al., 2020; Esfandiari and Morris, 2020). Since the South Sumatera province had only one coal-fired power plant and other industries rather than coal-fired power plants was the primary origin of $\mathrm{SO}_{2}$ emissions in this region. Hence, we assumed the significant reduction in $\mathrm{SO}_{2}$ concentrations in the study area due to the closure of the industries and the termination of fullscale production of several industries. Additionally, fewer vehicle emissions also partially reduced concentrations of $\mathrm{SO}_{2}$ in the study area. Previous studies revealed significant decreases of $\mathrm{SO}_{2}$ levels due to the lockdown policy. Ghahremanloo et al. (2021) found about $71 \%$ reduction of $\mathrm{SO}_{2}$ concentrations in Wuhan, China during the lockdown period. Li and Tartarini (2020) also found $50 \%$ reduction in $\mathrm{SO}_{2}$ concentrations during the COVID-19 lockdown in Singapore.

Furthermore, the average tropospheric $\mathrm{NO}_{2}$ concentration in study area revealed a significant reduction during LSSR phase 1 and LSSR phase 2 that were 34.76\% and 19.30\%, respectively (Table 1). Also, CO pollutants with $7.51 \%$ and $12.70 \%$ reductions during the subsequent LSSR phases (Table 1). Before the LSSR period, the center part of study area was recorded the highest amount of $\mathrm{NO}_{2}\left(205-263 \times 10^{13}\right.$ molecule $\mathrm{cm}^{-2}$ ) and $\mathrm{CO}\left(95-100\right.$ ppbv) (Figs. 4(a) and 5(a)). $\mathrm{NO}_{2}$ and $\mathrm{CO}$ pollutants were primarily spread in the atmosphere from emissions from cars, trucks and buses and power plants that burned fossil fuel. Palembang city which located in the center part of study area had high amounts of $\mathrm{NO}_{2}$ and $\mathrm{CO}$, this area was a mega urban city in the South of Sumatera Province where it had heavy traffic area that lead to high vehicles emission. This result was consistent with findings by Garg et al. (2001) who identified the primary contributors of $\mathrm{NO}_{2}$ in several mega cities in India, they found the transportation sector as the highest contributors of $\mathrm{NO}_{2}$ emissions in the city. Moreover, many studies have speculated that areas with low $\mathrm{CO}$ level were frequently related to the topography factor (Filonchyk et al., 2020). Low CO levels were usually located in the high elevation areas because of the low level of emission activities and low amount of atmospheric columns (Zhang et al., 2016). 

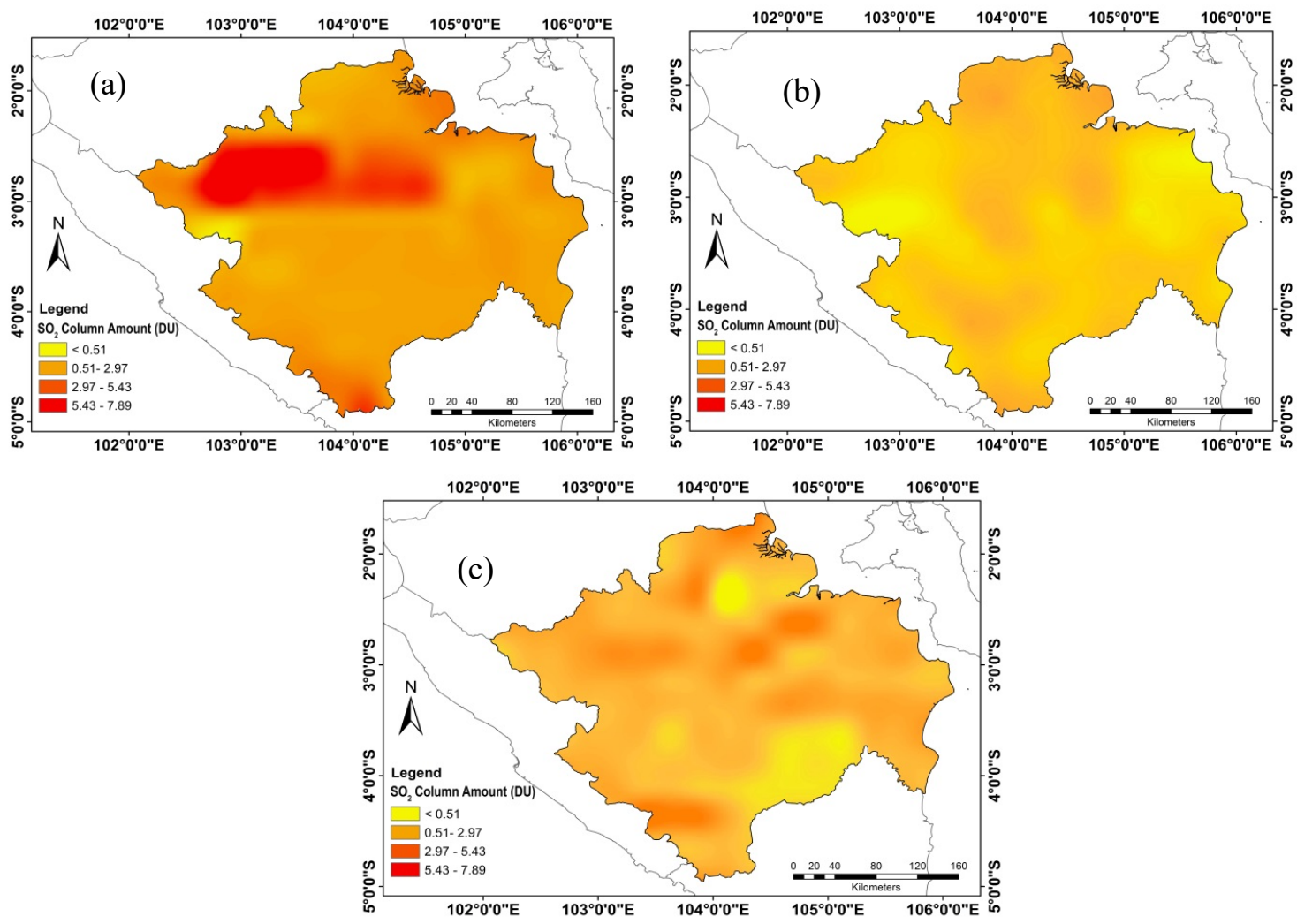

Fig. 3. Spatial distribution of $\mathrm{SO}_{2}$ concentration estimated with the NASA's Aura Satellite over study area (a) before the LSSR, (b) during the LSSR phase 1 and (c) during the LSSR phase 2.
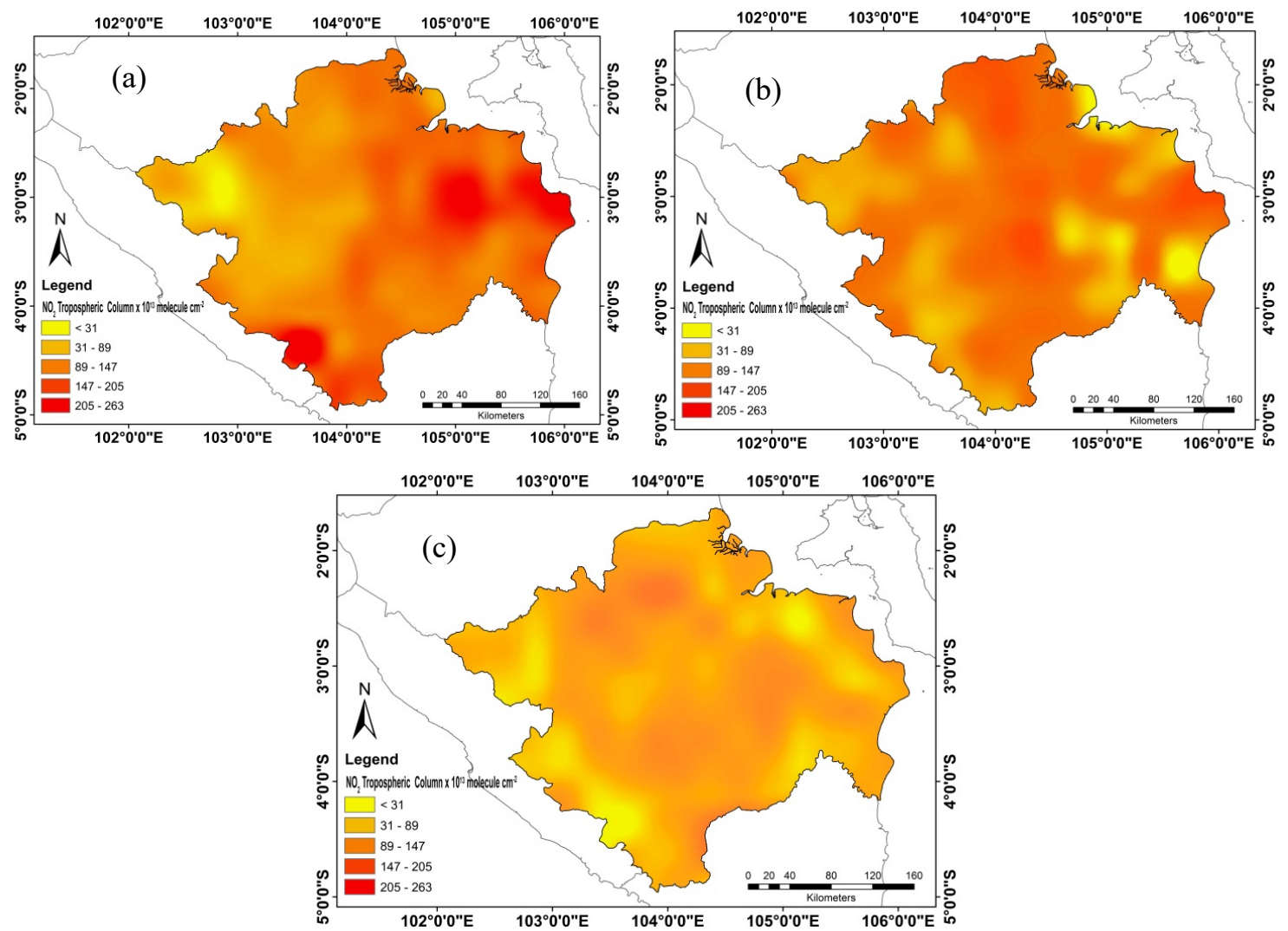

Fig. 4. Spatial distribution of $\mathrm{NO}_{2}$ concentration estimated with the NASA's Aura Satellite over study area (a) before the LSSR, (b) during the LSSR phase 1 and (c) during the LSSR phase 2. 

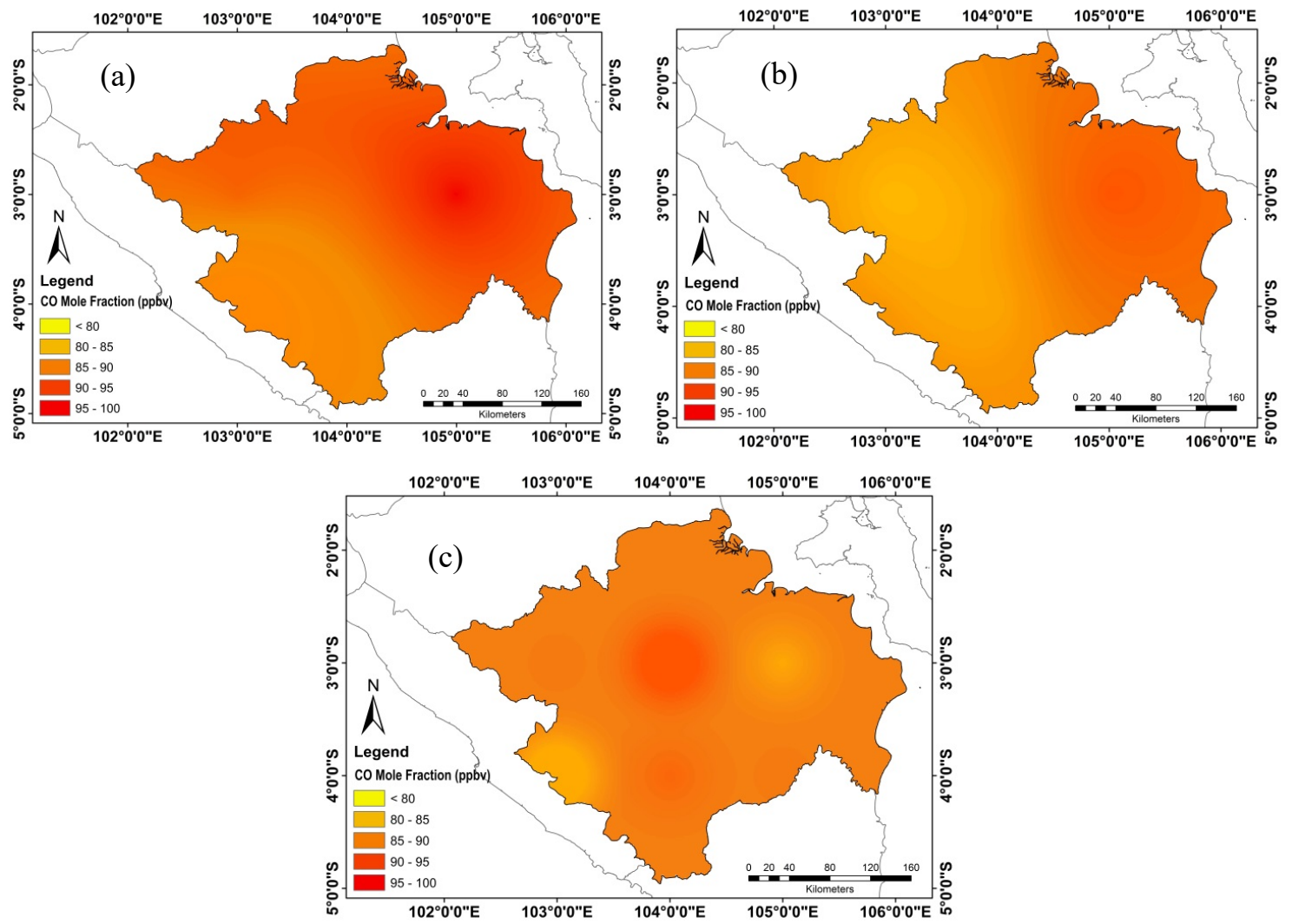

Fig. 5. Spatial distribution of CO concentration estimated with the NASA's Aqua Satellite over study area (a) before the LSSR, (b) during the LSSR phase 1 and (c) during the LSSR phase 2.

However, $\mathrm{NO}_{2}$ and $\mathrm{CO}$ pollutant levels recorded dropped after the LSSR implementation (Figs. 4(b)-4(c), and 5(b)-5(c)). During the LSSR, transportation and industrial activities were restricted, although power plants and biomass burning were still remained active in some areas, which then slightly increasing $\mathrm{NO}_{2}$ and $\mathrm{CO}$ pollutants in air. The decrease in air pollutant concentration was related to better air quality index (AQI), thus we compared our result with other provinces in Indonesia like Jakarta and West Java that both also had high COVID-19 cases and applied LSSR to avoid a larger scale transmission around the area. According to study by Pramana et al. (2020), they revealed that the air quality index from Jakarta, Banten and West Java provinces also showed better changes during the LSSR period.

\subsection{The Association between Air Pollutants and Case Fatality Rate of COVID-19}

To obtain the case fatality rate of COVID-19 over study area, we calculated the ratio between confirmed deaths (182 deaths) and confirmed cases (3724 cases) in study area, thus the case fatality rate of COVID-19 was $4.89 \%$. The case fatality rate value was higher as compared with other cities in China. The case fatality rate has been used to evaluate and compare the severity of COVID-19 epidemic between cities or countries (Kim et al., 2020). Our result found that the case fatality rate of COVID-19 was positively associated with $\mathrm{PM}_{10}$ concentration $(r=0.514, \mathrm{p}<$ 0.05) (Table 2). This result was in agreeement with findings by Yao et al. (2020) that the case fatality rate of COVID-19 was significantly correlated with $\mathrm{PM}_{10}$ in 49 Chinese cities. Another study by Hou et al. (2020) also found the same result that they revealed a significant positive association between long-term $\mathrm{PM}_{10}$ levels and the case fatality rate of COVID-19. To support this result, we conducted the back trajectories in the study area (Fig. 6). By using the back trajectory we would like to know where is the possible sources of $\mathrm{PM}_{10}$ during the LSSR, because based on the LSSR policy, industries and factories operation were restricted. The period of the back trajectories was selected at the same duration with the LSSR implementation (May 20-June 2, 2020). Fig. 6 revealed the hotspots of burning activities in the South Sumatera region were near 
Table 2. Spearman correlation between case fatality rate of COVID-19 with air pollutants.

\begin{tabular}{llllll}
\hline Parameter & Case Fatality Rate & $\mathrm{PM}_{10}$ & $\mathrm{SO}_{2}$ & $\mathrm{NO}_{2}$ & $\mathrm{CO}$ \\
\hline Case Fatality Rate & 1 & $0.514^{*}$ & 0.113 & -0.038 & -0.016 \\
$\mathrm{PM}_{10}$ & $0.514^{*}$ & 1 & 0.078 & $0.495^{*}$ & 0.313 \\
$\mathrm{SO}_{2}$ & 0.113 & 0.078 & 1 & -0.102 & 0.259 \\
$\mathrm{NO}_{2}$ & -0.038 & $0.495^{*}$ & -0.102 & 1 & 0.111 \\
$\mathrm{CO}$ & -0.016 & 0.313 & 0.259 & 0.111 & 1 \\
\hline
\end{tabular}

*Correlation is significant at the 0.05 level (2-tailed).

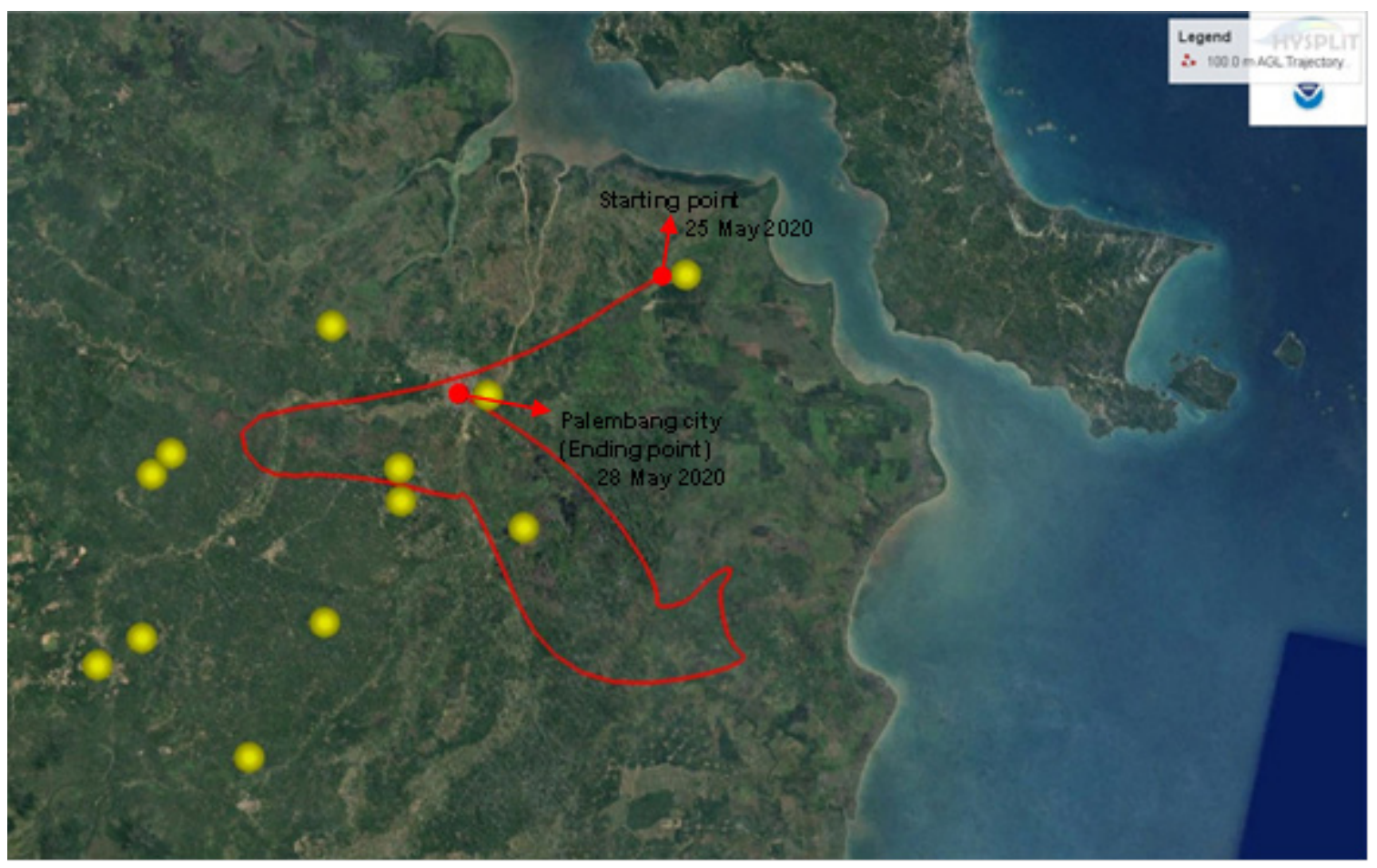

Fig. 6. The backward trajectory air pollutant of Palembang city during the LSSR (25-28 May 2020) with red line is a trajectory line at $100 \mathrm{~m}$ above ground level. The yellow dot features are active fire locations from satellites during the same duration.

to the Palembang city but they were not the major sources of emission. This study found the primary sources of the $\mathrm{PM}_{10}$ were from the northeast area. The $\mathrm{PM}_{10}$ emission could affect the human's cardiovascular system because it could enter into lung tissues and finally cause a severe inflammation (Ciencewicki and Jaspers, 2007). Other previous studies have found that long-term exposure to $\mathrm{PM}_{10}$ might harm lung functions and cause death (Bloemsma et al., 2016). If we compared our findings with previous studies of SARS-CoV-1 in 2003 year, the risk of death from SARS-CoV-1 increased when the air pollution index (API) increased (Cui et al., 2003). It concluded that the risk of death from SARS-CoV-1 and SARS-CoV-2 (COVID-19) that caused by air pollutants were almost similar.

However, there was weak correlation between the case fatality rate of COVID-19 and $\mathrm{SO}_{2}, \mathrm{NO}_{2}$ and $\mathrm{CO}(r<0.1, p>0.05)$ (Table 2). This study suggested that these gaseous had more significant relationship with incidence and transmissibility of COVID-19. Hou et al. (2020) also noted the same result that they found weak correlation between the case fatality rate of COVID-19 and $\mathrm{SO}_{2}$, $\mathrm{NO}_{2}$ and $\mathrm{O}_{3}$. As a whole, our findings obtained a positive association between $\mathrm{PM}_{10}$ level and the case fatality rate of COVID-19, that suggesting that long term $\mathrm{PM}_{10}$ exposure that prior to the LSSR period might increase sensitivity of resident to COVID-19. Limited by ground monitoring air pollutants data in study area during the pandemic situation, thus we analyzed $\mathrm{PM}_{10}, \mathrm{SO}_{2}, \mathrm{NO}_{2}$ and CO levels using high spatial resolution satellite (e.g., $1 \mathrm{~km} \times 1 \mathrm{~km})$. Therefore, for future studies, it needs to use hyperspectral images to obtain air pollutant data for getting better accuracy. 
The average $\mathrm{SO}_{2}, \mathrm{NO}_{2}, \mathrm{CO}$ and $\mathrm{PM}_{10}$ concentrations during the LSSR indicated a notable reduction over study area such as $98.90 \%, 34.79 \%, 12.70 \%$ and $11.54 \%$, respectively. The highest reduction of pollutants was at the second phase of LSSR. The reduction was due to a policy during the LSSR that commanded industrial operations either shut down or worked with limited capacity. Furthermore, this social distance policy recommended the people to stay at home thus it decreased vehicles emissions. The back trajectory analysis found in the limited of major industrial and transportation activities, biomass burning activities contributed as a primary source of particulate matter emission during the LSSR period in study area. The study also highlighted the $\mathrm{PM}_{10}$ concentration was associated with the case fatality rate of COVID-19 $(r=0.514, p<0.05)$. Thus, the higher $\mathrm{PM}_{10}$ concentration, the higher case fatality rate of COVID-19. This was because the $\mathrm{PM}_{10}$ increased a risk of mortality due to pulmonary diseases. These results of study could assist in arranging better air pollution management and COVID-19 transmission control.

\section{ACKNOWLEDGMENTS}

The author would like to acknowledge a support from the PNBP Faculty of Engineering, Universitas Sriwijaya under the Sainstek Research Grant Scheme for 2020 year (Decree No.: 0474/UN9.FT/TU.SK/2020). We also wished to thank the South Sumatera Health Department for providing COVID-19 cases data

\section{REFERENCES}

Ahlawat, A., Wiedensohler, A., Mishra, S.K. (2020). An overview on the role of relative humidity in airborne transmission of SARS-CoV-2 in indoor environments. Aerosol Air Qual. Res. 20, 1856-1861. https://doi.org/10.4209/aaqr.2020.06.0302

Babu, S.R., Rao, N.N., Kumar, S.V., Paul, S. Pani, S.K. (2020). Plausible role of environmental factors on COVID-19 transmission in the Megacity Delhi, India. Aerosol Air Qual. Res. 20, 20752084. https://doi.org/10.4209/aaqr.2020.06.0314

Boersma, K.F., Eskes, H.J., Veefkind, J.P., Brinksma, EJ., Van Der A, R.J., Sneep, M., Bucsela, E.J. (2007). Near-real time retrieval of tropospheric $\mathrm{NO}_{2}$ from OMI. Atmos. Chem. Phys. 7, 21032118. https://doi.org/10.5194/acp-7-2103-2007

Chowdhury, M.T., Sarkar, A., Paul, S.K., Moktadir, M.A. (2020). A case study on strategies to deal with the impacts of COVID-19 pandemic in the food and beverage industry. Oper. Manag. Res. 1-13. https://doi.org/10.1007/s12063-020-00166-9

Ciencewicki, J., Jaspers, I. (2007). Air pollution and respiratory viral infection. Inhalation Toxicol. 19, 1135-1146. https://doi.org/10.1080/08958370701665434

Cui, Y., Zhang, Z.F., Froines, J., Zhao, J., Wang, H., Yu, S.Z., Detels, R. (2003). Air pollution and case fatality of SARS in the People's Republic of China: An ecologic study. Environ. Health 2, 15. https://doi.org/10.1186/1476-069X-2-15

Dutheil, F., Baker, J.S., Navel, V. (2020). COVID-19 as a factor influencing air pollution? Environ. Pollut. 263, 114466. https://doi.org/10.1016/j.envpol.2020.114466

Esfandiari, S., Morris, M. (2020). These are all the companies who have shut down operations in China over the deadly Wuhan coronavirus outbreak. https://www.businessinsider.com/wuhancoronavirus-whichcompanies-shut-down operations-move-employees-2020-1 (accessed 5 May 2020).

Ezani, E., Brimblecombe, P., Asha'ari, Z.H., Fazil, A.A., Ismail, S.N.S., Ramly, Z.T.A., Khan, M.F. (2021). Indoor and outdoor exposure to $\mathrm{PM}_{2.5}$ during COVID-19 lockdown in Suburban Malaysia. Aerosol Air Qual. Res. 21, 200476. https://doi.org/10.4209/aaqr.2020.07.0476

Filonchyk, M., Hurynovich, V., Yan, H., Gusev, A., Shpilevskaya, N. (2020). Impact assessment of COVID-19 on variations of $\mathrm{SO}_{2}, \mathrm{NO}_{2}, \mathrm{CO}$ and $\mathrm{AOD}$ over east China. Aerosol Air Qual. Res. 20, 1530-1540. https://doi.org/10.4209/aaqr.2020.05.0226

Garg, A., Shukla, P.R., Bhattacharya, S., Dadhwal, V.K. (2001). Sub-region (district) and sector level 
$\mathrm{SO}_{2}$ and $\mathrm{NO}_{x}$ emissions for India: Assessment of inventories and mitigation flexibility. Atmos. Environ. 35, 703-713. https://doi.org/10.1016/S1352-2310(00)00316-2

Ghahremanloo, M., Lops, Y., Choi, Y., Mousavinezhad, S. (2021). Impact of the COVID-19 outbreak on air pollution levels in East Asia. Sci. Total Environ. 754, 142226. https://doi.org/10.1016/j.s citotenv.2020.142226

Hou, C.K., Qin, Y.F., Liu, Q. L., Yang, X.Y., Wang, H. (2020). Impact of long-term air pollution on the case fatality rate of COVID-19. Res. Square https://doi.org/10.21203/rs.3.rs-42283/v1

Kanniah, K.D., Zaman, N.A.F.K., Kaskaoutis, D.G., Latif, M.T. (2020). COVID-19's impact on the atmospheric environment in the Southeast Asia region. Sci. Total Environ. 736, 139658. https://doi.org/10.1016/j.scitotenv.2020.139658

Kim, D.H., Choe, Y.J., Jeong, J.Y. (2020). Understanding and interpretation of case fatality rate of coronavirus disease 2019. J. Korean Med. Sci. 35, e137. https://doi.org/10.3346/jkms.2020.35. e137

Lave, L.B., Seskin, E.P. (2013). Air pollution and human health. Routledge.

Li, J., Tartarini, F. (2020). Changes in air quality during the COVID-19 lockdown in Singapore and associations with human mobility trends. Aerosol Air Qual. Res. 20, 1748-1758. https://doi.org/10.4209/aaqr.2020.06.0303

Ling, S.H., van Eeden, S.F. (2009). Particulate matter air pollution exposure: Role in the development and exacerbation of chronic obstructive pulmonary disease. Int. J. Chron. Obstruct. Pulmon Dis. 4, 233-243. https://doi.org/10.2147/COPD.S5098

Liu, J., Zhou, J., Yao, J., Zhang, X., Li, L., Xu, X., Yan, J. (2020). Impact of meteorological factors on the COVID-19 transmission: A multi-city study in China. Sci. Total Environ. 726, 138513. https://doi.org/10.1016/j.scitotenv.2020.138513

Ma, Y., Zhao, Y., Liu, J., He, X., Wang, B., Fu, S., Luo, B. (2020). Effects of temperature variation and humidity on the death of COVID-19 in Wuhan, China. Sci. Total Environ. 724, 138226. https://doi.org/10.1016/j.scitotenv.2020.138226

NASA (2020). Airborne nitrogen dioxide plummets over China. NASA Earth Observatory. https://earthobservatory.nasa.gov/images/146362/airborne-nitrogen-dioxide-plummetsover-china

Pani, S.K., Lin, N.H., RavindraBabu, S. (2020). Association of COVID-19 pandemic with meteorological parameters over Singapore. Sci. Total Environ. 740, 140112. https://doi.org/1 0.1016/j.scitotenv.2020.140112

Patra, S.S., Panda, S., Das, T., Ramasamy, B. (2021) COVID-19 fatality: Statistical evidence to engender the need for focal shift from air pollutants to multi-dimensional intervention. Aerosol Air Qual. Res. 20, 200410. https://doi.org/10.4209/aaqr.2020.07.0410

Pramana, S., Paramartha, D.Y., Adhinugroho, Y., Nurmalasari, M. (2020). Air pollution changes of Jakarta, Banten, and West Java, Indonesia during the first month of COVID-19 pandemic. J. Bus. Econ. Environ. Stud. 10, 15-19. https://doi.org/10.13106/jbees.2020.vol10.no4.15

Ranjan, A.K., Patra, A.K., Gorai, A.K. (2020). Effect of lockdown due to SARS COVID-19 on aerosol optical depth (AOD) over urban and mining regions in India. Sci. Total Environ. 745, 141024. https://doi.org/10.1016/j.scitotenv.2020.141024

Ravindra, K., Singh, T., Pandey, V., Mor, S. (2020). Air pollution trend in Chandigarh city situated in Indo-Gangetic Plains: Understanding seasonality and impact of mitigation strategies. Sci. Total Environ. 729, 138717. https://doi.org/10.1016/j.scitotenv.2020.138717

Rendana, M. (2020). Impact of the wind conditions on COVID-19 pandemic: A new insight for direction of the spread of the virus. Urban Clim. 34, 100680. https://doi.org/10.1016/j.uclim.2 020.100680

Rolph, G., Stein, A., Stunder, B. (2017). Real-time environmental applications and display system: READY. Environ. Modell. Software 95, 210-228. https://doi.org/10.1016/j.envsoft.2017.06.025

Swietlicki, E., Puri, S., Hansson, H.C., Edner, H. (1996). Urban air pollution source apportionment using a combination of aerosol and gas monitoring techniques. Atmos. Environ. 30, 27952809. https://doi.org/10.1016/1352-2310(95)00322-3

Tosepu, R., Gunawan, J., Effendy, D.S., Lestari, H., Bahar, H., Asfian, P. (2020). Correlation between weather and Covid-19 pandemic in Jakarta, Indonesia. Sci. Total Environ. 725, 138436. https://doi.org/10.1016/j.scitotenv.2020.138436

World Health Organization (WHO) (2020). Considerations for Quarantine of Individuals in the 
Context of Containment for Coronavirus Disease (COVID-19): Interim Guidance, 19 March 2020 (No. WHO/2019-nCoV/IHR Quarantine/2020.2), World Health Organization.

Xu, K., Cui, K., Young, L.H., Hsieh, Y.K., Wang, Y.F., Zhang, J., Wan, S. (2020). Impact of the COVID19 event on air quality in central China. Aerosol Air Qual. Res. 20, 915-929. https://doi.org/1 0.4209/aaqr.2020.04.0150

Yang, W., Elankumaran, S., Marr, L.C. (2011). Concentrations and size distributions of airborne influenza A viruses measured indoors at a health centre, a day-care centre and on aeroplanes. J. R. Soc. Interface 8, 1176-1184. https://doi.org/10.1098/rsif.2010.0686

Yao, Y., Pan, J., Wang, W., Liu, Z., Kan, H., Qiu, Y., Wang, W. (2020). Association of particulate matter pollution and case fatality rate of COVID-19 in 49 Chinese cities. Sci. Total Environ. 741, 140396. https://doi.org/10.1016/j.scitotenv.2020.140396

Zhang, L., Jiang, H., Lu, X., Jin, J. (2016). Comparison analysis of global carbon monoxide concentration derived from Sciamachy, Airs, and Mopitt. Int. J. Remote Sens. 37, 5155-5175. https://doi.org/10.1080/01431161.2016.1230282

Zoran, M.A., Savastru, R.S., Savastru, D.M., Tautan, M.N. (2020). Assessing the relationship between surface levels of $\mathrm{PM}_{2.5}$ and $\mathrm{PM}_{10}$ particulate matter impact on COVID-19 in Milan, Italy. Sci. Total Environ. 738, 139825. https://doi.org/10.1016/j.scitotenv.2020.139825 